\title{
Augmented Reality Application using Dynamic Location-Based Tracking of Taman Ayun Temple
}

\author{
Sarah Olivia Meily ${ }^{\mathrm{a} 1}$, Putu Wira Buana ${ }^{\mathrm{a} 2}$, Mohd Farhan bin MD. Fudzee ${ }^{\mathrm{b} 3}$ \\ alnformation Technology, Udayana University, Ind onesia \\ 1oliviameily@student.unud.ac.id, ${ }^{2}$ wbhuana@it.unud.ac.id \\ bUniversity Tun Hussein Onn Malaysia \\ 3farhan@uthm.edu.my
}

\begin{abstract}
Taman Ayun Temple is a world cultural heritage in Bali. Based on observations, information regarding the location at Taman Ayun Temple is still not optimal. This study aims to design an application that displays location information using markerless augmented reality. Markerless $A R$ is a technology that displays virtual objects into the real world using GPS, digital compass, and accelerometer. The application is designed using the Wikitude SDK platform and displays information on location, description, image, distance from the user, and location direction. Data is stored in a database server and managed using the web server. Applications are in Indonesian and English. The testing compares the actual distance with the distance displayed in the application using devices with different OS and RAM. Application speed is less than 1 second depending on RAM and internet speed, while location accuracy depends on smartphone GPS accuracy with a difference of less than 10 meters from the actual distance.
\end{abstract}

Keywords: augmented reality, markerless, geo AR, Wikitude, Android

\section{Introduction}

Indonesia is a country known for its natural and cultural wealth. Bali is one of Indonesia's tourism icons because of its natural beauty and cultural wealth [1]. The population of Bali is dominated by Hindus who believe in and worship Gods [2]. Dewata is the plural term for the Gods. This is the reason Bali is called the Island of the Gods and the Island of a Thousand Temples [3]. The existence of temples in Bali, apart from the spiritual aspect, which is the sthana of the Gods, has developed into historical relics and become tourism objects because of their beautifularchitecture. One of the temples that have been named a world cultural heritage in Bali is Taman Ayun Temple. Taman Ayun Temple is located in Mengwi District, Badung Regency, Bali Province. Taman Ayun Temple is a place of prayer for Hindus which functions as Penyawangan or representative temple so that the Mengwi people who want to pray to big temples such as Besakih Temple, Uluwatu Temple, Batur Temple, Batukaru Temple, Ulundanu, and others simply come to Taman Ayun Temple [4].

Besides being visited by local people to pray, Taman Ayun Temple is also visited by many tounists from various countries. However, based on direct observations, the inf ormation regarding the location directions of places and buildings at Taman Ayun Temple is still not optimal. Tour guides will only guide tourists who come in large groups, while tourists who come with a few people will be left around without knowing the name of the place and the function or use of the place they have visited. Based on these problems, this research aims to produce an Android-based mobile application that can display location information that can be used directly when the user is in Taman Ayun Temple. Technology that is suitable for use as an interesting and interactive media of information is Augmented Reality. Augmented reality is a technology that displays virtual objects or digital objects in the real world [5]. 
Augmented reality technology is divided into two types, namely markerless and marker-based augmented reality. This study implements markerless aug mented reality in the Taman Ay un AR application by utilizing a mobile GPS, digital compass, and accelerometer to determine the coordinates of the user's location points. It is developed by using Geo AR on the Wikitude SDK Android Javascript API platform and Android Studio to design Android applications.

A system can be divided into two types, namely static and dynamic. Static systems are systems that are designed and built only at one stage who se value is certain. Whereas a dynamic system is known as a non-static system, meaning that the system response can change at any time to the identified variables [6]. One of the AR studies that applies a dynamic system is researched by Ligia Prapta on android-based kanji recognition. This research uses the Vuforia cloud recognition feature, which functions as a cloud database marker for collecting images from the kanji letters that will be recognized [7]. Another research is by Astiti about the circulation learning and roid application using dynamic video. This application uses a local server to save the URL of the displayed video storage location. The displayed video can change according to the URL accessed on the local server [8].

Research specifically with AR location-based tracking has never been applied to dynamic systems before. So innovation in this research is one of its advantages. Taman Ayun AR application is dynamic, where location data will be stored in the database server. The addition of new locations to the system can be done easily by a web server without making significant changes to the applications built. The information displayed is the location points around the user and their detailed information, such as the location name, location image, location description, and the distance between the user and the location. The application is built in Indonesian and English so that both domestic and foreign tourists can use it.

The information about places in Taman Ayun Temple can be displayed more attractively and interactively to the user through this research. Visitors who come to Taman Ayun Temple attractions can find it easier and more independent to obtain information regarding locations around them.

\section{Research Method}

\subsection{Related Study}

The Taman Ayun AR application design has similarities and/or relationships from several studies conducted, some of which are as follows. The first research is the DewataAR application, an Android-based augmented reality application for Pura in Bali, which uses a brochure as a marker and displays 3-dimensional (3D) objects from Bali temples. This application was built using Unity $3 \mathrm{D}$ tools and using the Vuf oria library [9]. Furthermore, research on augmented reality folklore Bali Lubdaka made in the LubdakaAR Android-based application. This application displays a 3D animation of Lubdaka's story using a pictorial storybook as a marker. This study uses Autodesk Maya tools to design 3D objects and Unity 3D and Wikitude SDK to develop aug mented reality [10]. The following research is an augmented reality ap plication for the introduction of traditional buildings in Panglipuran Village. This application uses Autodesk Maya and Unity tools in its design. The output produced in this study is building information in the form of 3D object animation, text, and audio narration with brochure media as a marker [11]. Subsequent research applies a markerless technique using GPS to obtain coordinate points of each location at Bengkulu University. This application is designed based on Android using the Eclipse IDE and the Augmented Reality BeyondAR framework. The location points are displayed in a map and seen through the AR camera after the user is at that location point [12].

Another AR research in tourism is Nugraha's research on the AR application of the Bali Museum. The application is designed to work by detecting markers and then displaying $3 \mathrm{D}$ objects and information from one Bali Museum object [13]. Other research by Adnin on home design 3D catalog application. The app works by displaying 3D home design objects from a scanned marker catalog. The application is designed with Unity 3D software and the Vuforia library [14]. AR's application is also carried out on research on the Magic Book, which aims to assist the learning process of animal recognition for kindergarten students. This study uses a catalog book of pictures of animal objects as a collection of markers. The results displayed are the 3D object of 
the animal along with the sound of the animal. The applicationis d esigned using Unity 3D software [15].

\subsection{System Overview}

The system overview is an overview to describe the process flow that occurs in the system, such as input, process, and output based on processed data. The system overview also shows the components involved in the system work process. An overview of the Taman Ayun AR locationbased tracking application can be seen in figure 1 .

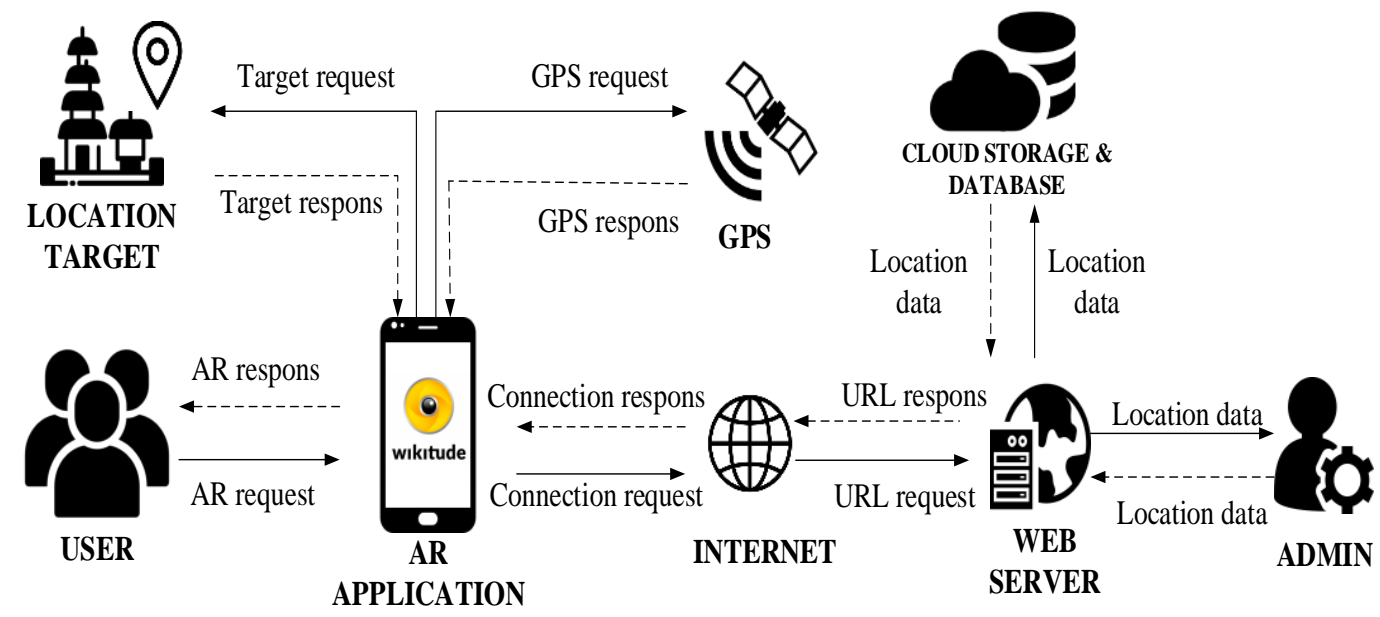

Figure 1. System Overview

Figure 1 is an overview of the Taman Ayun AR Application System. The location-based tracking system created is dynamic; in other words, the displayed location data can be added, edited, deleted, or managed as needed via a web server. The dynamic system runs by requesting POI (Point of Interest) data to the database server to be displayed on the mobile application. The process of requesting data to the server only runs when connected to the internet and GPS. The admin has previously added the data stored in the database server via the web server. When it is necessary to add, edit, and delete location data, there is no need to change the application's code structure, but it can be managed via a web server. This is what causes this system to be called dynamic. First, the smartphone must be installed with the Taman Ayun AR application, designed using the Wikitude platform. The smartphone must be connected to the internet and Global Positioning System (GPS) to use the application. The smartphone's GPS receiver feature will be connected directly to the GPS satellite to receive location data on its coordinates. After that, the application will request and receive data from the database server in JSON format. When a data request occurs, the location data that has been stored in the database will then be displayed on the mobile application. The location point that appears on the smartphone will contain the name of the location or object, important information regarding the object, and the distance from the user's location.

\subsection{Use Case Diagram}

Use case diagrams to represent user interactions with the system, how many users are involved in implementing the application, and describe what activities each user can carry out. Use case diagram the Taman Ayun AR application can be seen in Figure 2. 


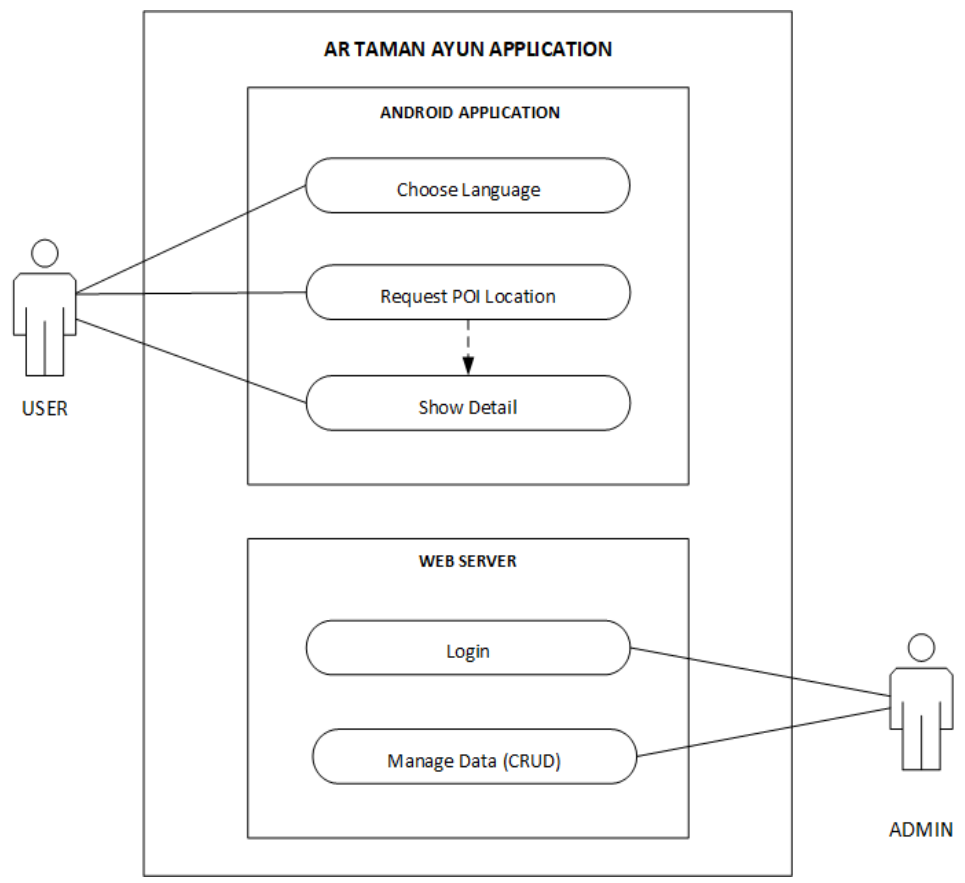

Figure 2. Use Case Diagram

Figure 2 shows the use case diagram of the Taman Ay un AR Application. The use case describes the interaction of each actor to the Taman Ayun AR application system. The Taman Ayun AR application use case has two actors, namely user, and admin. Some of the Taman Ayun AR application's Android system's functionalities that the user can directly access are selecting a language, requesting data to display POl locations, and displaying detailed POl inf ormation. While on the web server, there is an admin as an actor, and the functionality of the system that can be accessed is the login and data management (CRUD) location.

\subsection{Application Flow}

The application flow design is made to make it easier to understand the flow of the system flow in the Taman Ayun AR application. This diagram contains the entire process from the first application run until the application is closed. The design of the Taman Ayun AR application flow can be seen in Figure 3.

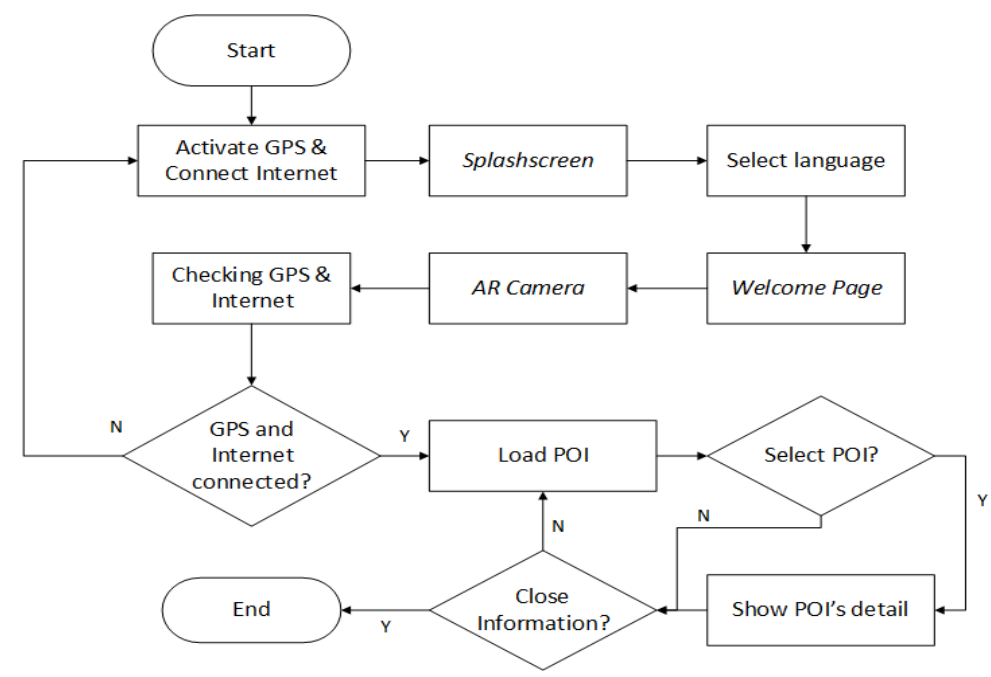

Figure 3. Application Flow Diagram 
Figure 3 is a flow chart of the Taman Ayun AR application. First, the user must activate GPS and internet connection to be able to use the application. The application will display a splash screen page for a few seconds and go to the welcome page that illustrates how to use the application. After that, the application will display the AR camera, followed by checking the GPS and intemet connection; when it is active, it auto matically loads the location data from the database server. After the data is successfully loaded, the location points (POI) will be displayed on the user's smartphone. Users can select the POI to display detailed location information from the POI selected by the user. Furthermore, the user can select another POl point or close the application.

\section{Result and Discussion}

\subsection{Web Server Implementation}

Taman Ayun AR application has two system implementations in the form of a web server system and an android application. Administrators use the web server implementation to manage location data displayed when users access the Android application. This function is what causes the system to be called dynamic. The location data displayed on the mobile application is dynamic because it is sufficiently managed via a web server without changing the application builder code structure.

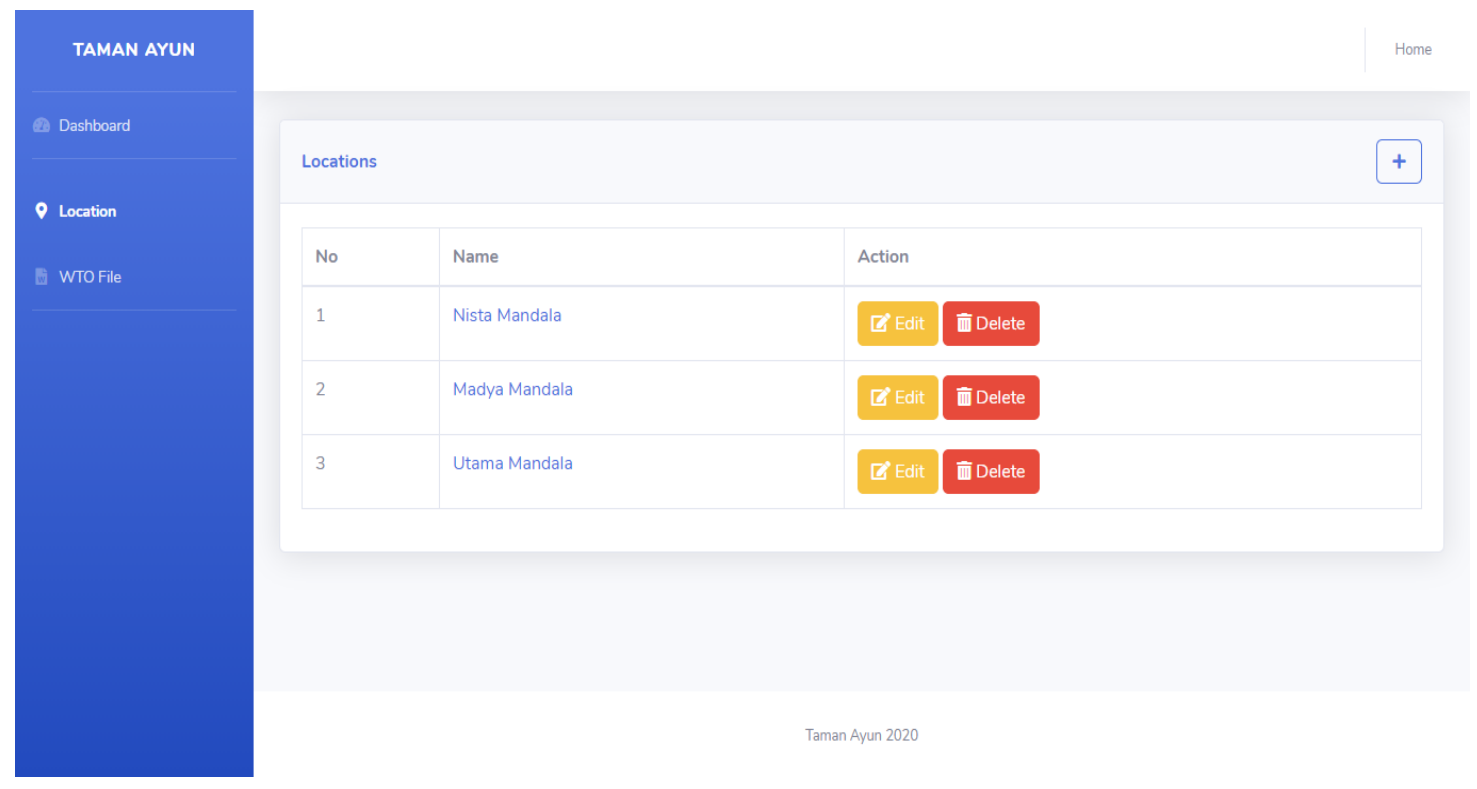

Figure 5. Web Server Implementation

Figure 5 implements the AR Taman Ayun application's web server admin interf ace to manage location data used to display virtual objects in mobile applications. On the web server system, the admin can add, edit, and delete location data. Data added via the web server will be stored in the database server to be requested and displayed on the mobile application. Location data consists of the location name, location image, latitude and longitude coordinates, and location description.

\subsection{Mobile Application Implementation}

AR Taman Ayun mobile application is designed to be accessed directly by users at Taman Ayun Temple. The applications are made in two language options: Indonesian and English. So that both local and foreign tourists can use this application, the data that will appear in this mobile application has previously been added by the admin via a web server and stored on the database server. 


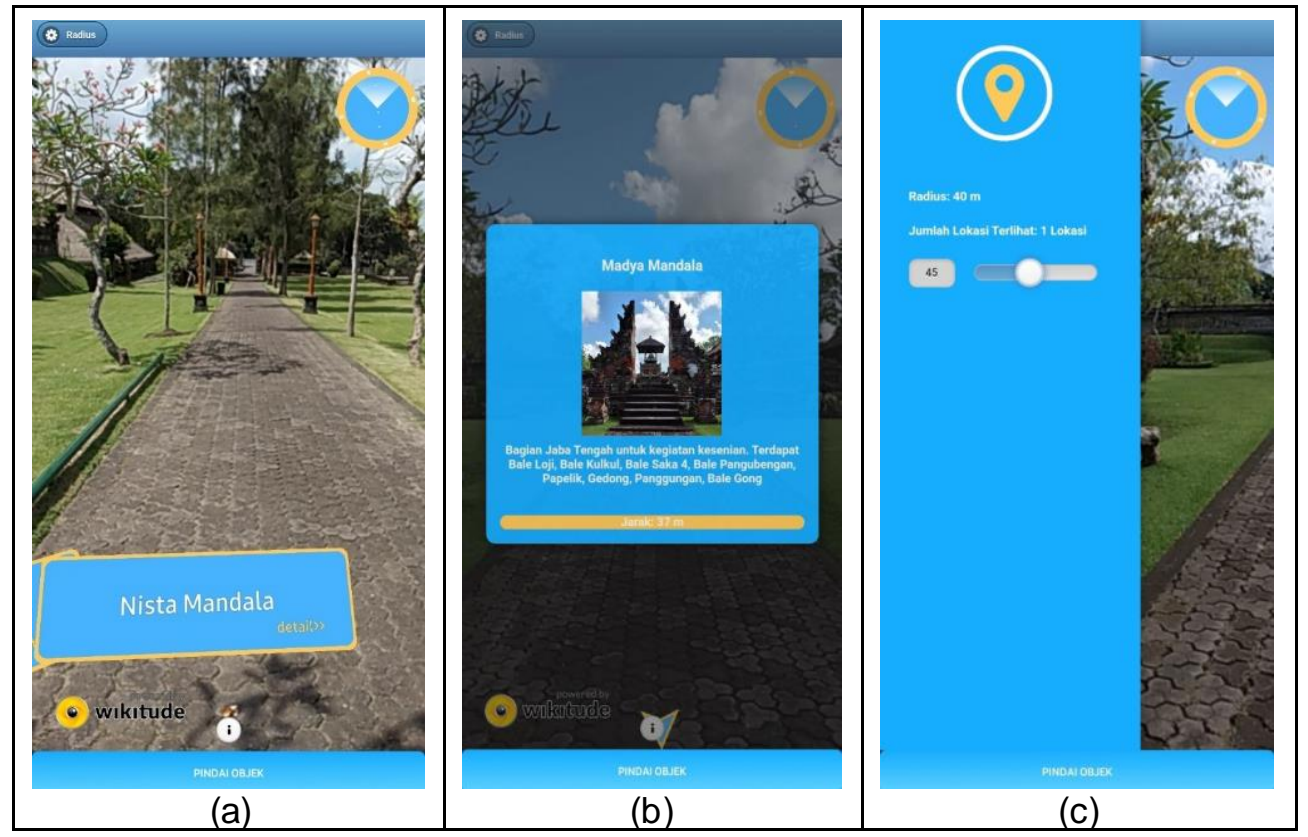

Figure 6. Load POI (a), POI Detail (b), Range SettingTab (c)

Figure 6 displays Load POI (a), which results from the Request POI process that is executed automatically when the application is run. So the user does not need to take any action for the request $\mathrm{POI}$ process. The user runs the application, and when the AR camera is displayed, the application automatically sends a POI data request to the database server. After that, Load POI data will be carried out, and the location points will be displayed in the application as shown in Figure 6 (a). Next, the POI Detail (b) will be displayed when the user selects one of the displayed location points. It contains the location name, image, location description, and location distance from the user's location. Users can also select the range setting tab (c) to set the radius of the location distance limit that the user wants to display.

\subsection{Application Testing}

Application testing is carried out to test the features of the Taman Ayun AR application. It aims to determine whether the application's functionality is running correctly or not. The test results are presented in Table 1.

Table 1. Application Testing Result

\begin{tabular}{|c|c|c|c|c|}
\hline No. & Feature & Scenario & Expected Results & Test Result \\
\hline 1. & Splash Screen & Run the application & $\begin{array}{l}\text { The splash screen } \\
\text { appears with the } \\
\text { application logo for } 4 \\
\text { seconds }\end{array}$ & Success \\
\hline 2. & Language Selection & $\begin{array}{l}\text { User selects the } \\
\text { language button on } \\
\text { the language } \\
\text { selection page }\end{array}$ & $\begin{array}{l}\text { All the inf ormation is } \\
\text { displayed in the } \\
\text { desired language }\end{array}$ & Success \\
\hline 3. & Welcome Page & $\begin{array}{l}\text { After selecting the } \\
\text { language, the user } \\
\text { will automatically go } \\
\text { to the welcome page }\end{array}$ & $\begin{array}{l}\text { Shows an illustration } \\
\text { of how to use the } \\
\text { application }\end{array}$ & Success \\
\hline 4. & Load POI & $\begin{array}{l}\text { User selects the } \\
\text { start button on the } \\
\text { welcome page }\end{array}$ & $\begin{array}{l}\text { Shows the camera } \\
\text { AR page and POI } \\
\text { Points will be } \\
\text { displayed }\end{array}$ & Success \\
\hline
\end{tabular}


Accredited Sinta 2 by RISTEKDIKTI Decree No. 30/E/KPT/2018

\begin{tabular}{ccccc}
\hline No. & Feature & Scenario & Expected Results & Test Result \\
\hline 5. & $\begin{array}{c}\text { Detailed Location } \\
\text { Information } \\
\text { POI Radius }\end{array}$ & $\begin{array}{c}\text { User selects a POI } \\
\text { point } \\
\text { User selects the } \\
\text { Radius button }\end{array}$ & $\begin{array}{c}\text { Shows detailed POI } \\
\text { information selected } \\
\text { Displays the number } \\
\text { of POI points in the } \\
\text { specified radius }\end{array}$ & Success \\
6. & Success \\
\hline
\end{tabular}

Table 1 is the result of testing the features of the application. The test results show that all the features of the ap plication run successfully according to the expected results. The main features of Location-Based Tracking will be explained in more detail and focus on us er testing in the next section.

\subsection{Location-Based Tracking Testing}

Location-Based Tracking is the main feature of this application. This testing was carried out on three types of devices with different specifications. The first is Samsung Galaxy J7 Pro with Android operating system Nougat (7.0) and 4GB RAM, the second is OPPO A5 2020 Pro with Android operating system Pie (9.0) and 3GB RAM, and the third is Samsung Galaxy A20s Pro with the operating system Android 10 and 4GB RAM. Testing is done by comparing the distance to the location shown on Google Maps with the results displayed on three devices.

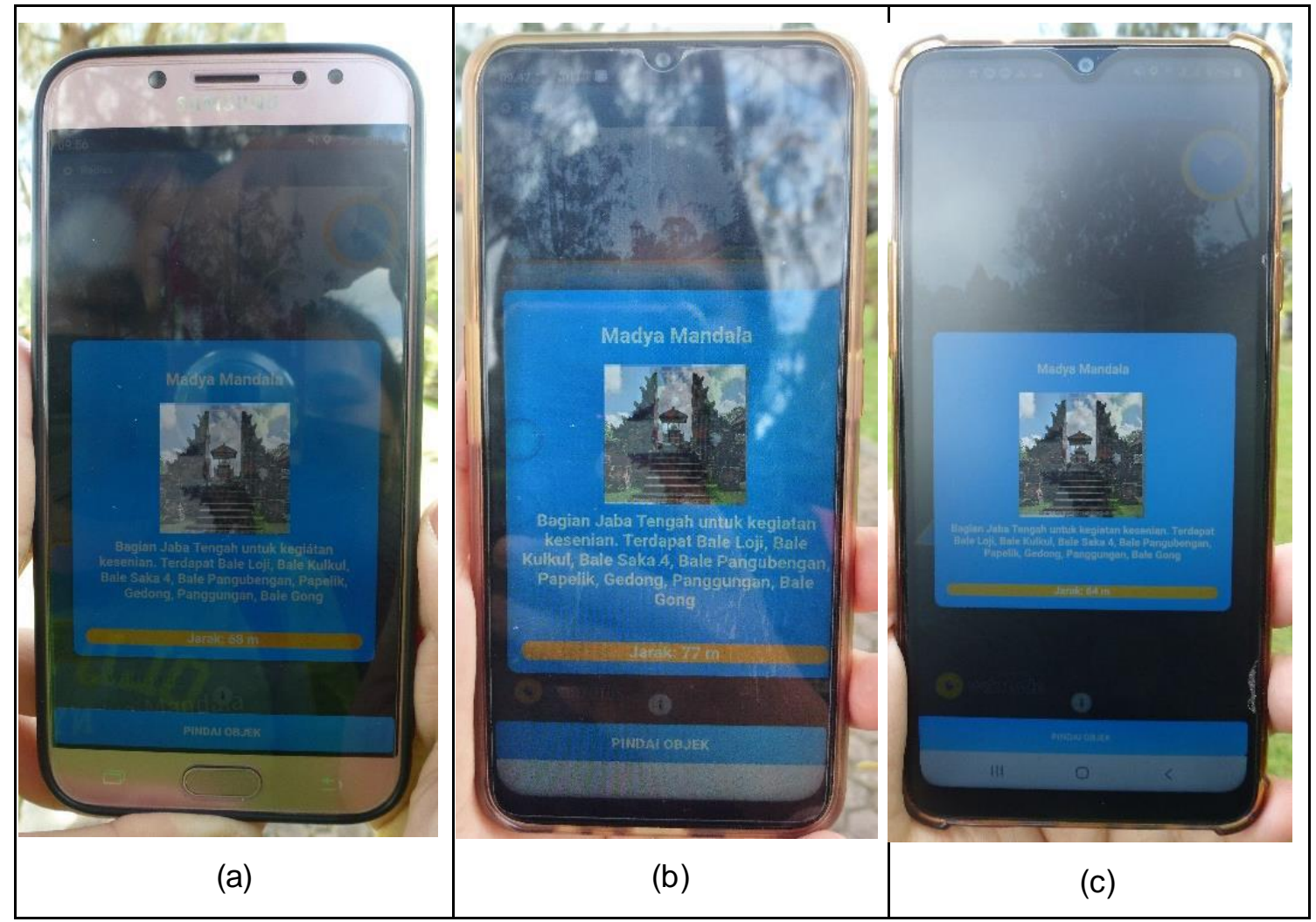

Figure 7. Samsung Galaxy J7 Pro (a), OPPO A5 2020 (b), Samsung Galaxy A20s (c)

Figure 7 is the result of testing on three devices at a location called Mandya Mandala with an actual distance of 65 meters. The analysis is performed on the speed of the device in displaying information and the accuracy of the distance displayed with the actual distance. The complete test results are presented in Table 2. 
Accredited Sinta 2 by RISTEKDIKTI Decree No. 30/E/KPT/2018

Table 2. Location-Based Tracking Testing Result

\begin{tabular}{cccc}
\hline Device Name & Speed & Distance & Error \\
\hline Samsung Galaxy J7 Pro & 0.8 seconds & 68 meters & No \\
OPPO A5 2020 & 0.8 seconds & 72 meters & No \\
Samsung Galaxy A20s & 0.7 seconds & 64 meters & No \\
\hline
\end{tabular}

Table 2 shows the test results on speed, distance, and error on each device. In terms of speed, the Samsung Galaxy A20 is 0.1 second ahead of the other two devices. In terms of distance accuracy, the Samsung Galaxy A20 is also the closest, with a distance of 64 meters, while the OPPO A5 2020 is the farthest with a distance of 72 meters. For system functionality, the three devices have no errors. However, based on the distance displayed, the difference with the actual distance does not exceed 10 meters, so it can be said that the location-based tracking feature is running well and accurately. Based on device specifications, the OPPO A5 2020 is indeed the device with the lowest RAM specifications. This proves that RAM capacity significantly affects application performance. The speed of the internet connection also affects the speed of the application in displaying information because the process of loading data from the database server requires an internet connection.

\section{Conclusion}

Taman Ayun AR application uses the Location-Based Tracking method on Augmented Reality technology to detect the user's location via a mobile GPS, digital compass, and accelerometer. The application design using the Wikitude SDK platform can integrate with the XML language. The Taman Ayun AR application is dynamic in providing data and managing data by the admin using the web server. Location information is displayed to users in location names, images, descriptions, and the distance between locations and users. Users can also set the distance limit or radius from the location that the user wants to display. This application is designed in Indonesian and English so that it can be used by local and foreign tourists.

The test was conducted on three devices with different Android OS types starting from Nougat (7.0), Pie (9.0), and Android 10, successfully running without any errors. Application access speed can function properly depending on the smartphone RAM capacity and internet network speed used, while the accuracy of the displayed location depends on the GPS accuracy of each smartphone with a difference of less than 10 meters from the actual distance.

\section{References}

[1] I. G. B. Rai Utama, "Keunikan Budaya dan Keindahan Alam sebagai Citra Destinasi Bali menurut Wisatawan Australia Lanjut Usia," Jurnal Kajian Bali (Journal of Bali Studies), vol. 6, no. 01, pp. 149-172, 2016.

[2] S. Saleh, "Kerukunan Umat Beragama di Denpasar Bali," Rumah Jurnal AL-FIKR, vol. 17, no. 1, pp. 167-175, 2013.

[3] A. A. Munandar, Istana Dewa Pulau Dewata, Depok: Komunitas Bambu, 2005.

[4] I. W. Ardika and I. N. Subadra, Warisan Budaya Dunia Pura Taman Ayun dan Pura Tirta Empul Sebagai Daya Tarik Wisata di Bali, 1st ed., Denpasar-Bali: Pustaka Larasan, 2018.

[5] S. C.-Y. Yuen, G. Yaoyuneyong and E. Johnson, "Augmented reality: An overview and five directions for AR in education," Journal of Educational Technology Development and Exchange, vol.4, no. 1, pp. 119-140, 2011, doi: 10.18785/JETDE.0401.10.

[6] L. R. Andhika, "Model Sistem Dinamis: Simulasi Formulasi Kebijakan Publik (Dynamic System Model: Simulation Method in Formulation Public Policy)", Jurnal Ekonomi \& Kebijakan Publik, vol. 10, no. 1, pp. 73-86, 2019.

[7] I. B. N. Ligia Prapta, I. K. G. Darma Putra and I. M. A. D. Suarjaya, "Aplikasi Augmented Reality Dinamis Pengenalan Huruf Kanji (AR-Kanji) Berbasis Android", Jurnal Merpati (Menara Penelitian Akademika Teknologi Informasi), vol. 6, no. 3, pp. 185-191, 2018, doi: 10.24843/JIM.2018.v06.i03.p05. 
[8] I. A. P. W. Astiti, G. M. A. Sasmita and M. Sukarsa, "Penerapan Augmented Reality Video Dinamis dalam Pembelajaran Peredaran Darah Berbasis Android", Jurnal Merpati (Menara Penelitian Akademika Teknologi Informasi), vol. 6, no. 3, pp. 174-184, 2018, doi: 10.24843/JIM.2018.v06.i03.p04.

[9] A. F. Waruwu, I. P. A. Bayupati and I. K. G. Darma Putra, "Augmented Reality Mobile Application of Balinese Hindu Temples: DewataAR", International Journal Computer Network and Information Security, vol. 2, no. 7, pp. 59-66, 2015, doi: 10.5815/ ijcnis.2015.02.07.

[10] I. K. G. Darma Putra, I. M. Suwija Putra and I. N. Adi Trig inarsa, "Augmented Reality Mobile Application of Balinese Story: LubdakaAR," The European Journal of IT and Project Management, 2019.

[11] A. A. N. H. Susila and D. M. S. Arsa, "Aplikasi Augmented Reality Pengenalan Bangunan Adat Desa Penglipuran," Jurnal Media Informatika Budidarma, vol. 4, no. 3, pp. 726-734, 2020, doi: $10.30865 / \mathrm{mib} . v 4 i 3.2208$.

[12] I. A. Fikri, D. Herumurti and H.R. Rahman, "Aplikasi Navigasi Berbasis Perangkat Bergerak dengan Menggunakan Platform Wikitude untuk Studi Kasus Lingkungan ITS," Jurnal Teknik ITS, vol. 5, no. 1, p. 48, 2016, doi: 10.12962/j23373539.v5i1.14511.

[13] I. G. A. Nugraha, I. K. G. Darma Putra and I. M. Sukarsa, "Rancang Bangun Aplikasi Android AR Museum Bali : Gedung Karangasem dan Gedung Tabanan”, Lontar Komputer, vol. 7, no. 2, pp. 93-103, 2016, doi: 10.24843/LKJITI.2016.v07.i02.p03.

[14] S. N. Adnin, I. B. K. Widiartha and I. M. Suksmadana, "Pembuatan Aplikasi Catalog 3D Desain Rumah Sebagai Sarana Promosi Dengan Menggunakan Unity3D", Lontar Komputer, vol. 7, no. 1, pp. 1-12, 2016, doi: 10.24843/LKJITI.2016.v07.i01.p01.

[15] I. D. G. W. Dhiyatmika, I. K. G. Darma Putra and N. M. I. M. Mandenni, "Aplikasi Augmented Reality Magic Book Pengenalan Binatanguntuk Siswa TK”, Lontar Komputer, vol. 6, no. 2, pp. 120-127, 2015. 